\title{
Reproductive dynamics of Leporinus obtusidens captured downstream from an important hydropower Station in Brazil
}

\author{
[Dinâmica reprodutiva de Leporinus obtusidens capturados a jusante de uma \\ importante usina hidrelétrica no Brasil] \\ E.S. Andrade, V.O. Felizardo, L.D.S. Murgas, M.M. Drumond, \\ M.G. Zangerônimo, S.F. Costa \\ Universidade Federal de Lavras - Lavras, MG
}

\begin{abstract}
This study evaluated the reproductive dynamics and gonadal morphology of piaparas (Leporinus obtusidens) captured downstream from the Funil Hydroelectric Power Station. The 107 piaparas evaluated were captured monthly from Sep 2006 to Aug 2007. The data were stratified among the seasons to evaluate gonad maturation and the reproductive period was determined by assessing the gonadosomatic index, hepatosomatic index, abdominal fat index (AFI), weight:length ratio, condition factor and sexual proportion. The reproductive period lasted from winter to summer (Jul-Mar) in females and from spring to autumn (Sept-Jun) in males. AFI was high during and after the reproductive period in females and only during the reproductive period in males. The highest HIS values for males and females were obtained in spring and summer (Sept-Mar). The females observed did not spawn and showed follicular atresia. These characteristics suggest that $L$. obtusidens does not use the study area as a reproductive site and probably migrates for this purpose.
\end{abstract}

Keywords: fish, reproduction, piracema, histology, gonad

\section{RESUMO}

Este estudo avaliou a dinâmica reprodutiva e a morfologia gonadal de piaparas (Leporinus obtusidens) capturados a jusante de uma usina hidrelétrica. Os 107 exemplares avaliados foram capturados mensalmente, de setembro de 2006 a agosto de 2007. Os dados foram estratificados entre as estações do ano para se avaliar a maturação gonadal, e o período reprodutivo foi determinado por meio da avaliação do índice gonadossomático, índice hepatossomático, indice de gordura abdominal (AFI), relação peso:comprimento, fator de condição e proporção sexual. O período reprodutivo foi observado do inverno para o verão, julho-março, para as fêmeas, e da primavera para o outono, setembro-junho, para os machos. AFI foi alto durante e após o período reprodutivo em fêmeas e apenas durante o período reprodutivo em machos. Os maiores valores para machos e fêmeas foram obtidos na primavera e no verão. As fêmeas observadas não desovaram e mostraram atresia folicular. Essas características sugerem que $\mathrm{L}$. obtusidens não usa a área de estudo como sítio reprodutivo e, provavelmente, realiza migração.

Palavras-chave: peixe, piracema, reprodução, gônada, histologia

\section{INTRODUCTION}

Identifying the reproductive period of different fish species is important to understand part of their reproductive strategy, which involves a set of characteristics and activities that guarantee reproductive success and population equilibrium for several generations. Fish undergo drastic gonad modifications throughout the annual reproductive cycle. These alterations can be assessed by calculating the gonadosomatic index, an important parameter for evaluating the reproductive status and functional condition of fish because it depicts gonadal development (Vazzoler, 1996; Agostinho et al., 2007).

Recebido em 19 de fevereiro de 2013

Aceito em 6 de agosto de 2013

E-mail: esandrade@bol.com.br 
During testicular maturation, the liver provides energy for reabsorption processes, testicular reorganization and gamete production. It also participates in the synthesis and secretion of hepatic substances involved in vitellogenesis. Therefore, a known maturation curve for a determined species allows us to evaluate the nutritional condition and resource mobilization capability of individuals (Querol et al., 2002).

The piapara (Leporinus obtusidens) is a total egg-laying species that migrates from October to February. Water reservoirs directly affect this species because the dams impede or delay the fish from swimming upstream, affecting their reproductive cycle (Agostinho et al., 2005).

The objectives of this work were to evaluate maturity stages in the reproductive period, the nutritional status and energy storage of male and female piaparas captured downstream from the Funil Hydroelectric Power Station, Rio Grande, Brazil, and to associate these variables to gonadal development.

\section{MATERIALS AND METHODS}

The specimens were captured downstream from the Funil Hydroelectric Power Station $\left(44^{\circ} 55^{\prime} \mathrm{W}\right.$ $21^{\circ} 05^{\prime} \mathrm{S}$ ) in the Rio Grande from Sept 2006 to Aug 2007, and the data were analyzed for each season. Of the 107 animals studied, 42 were males and 65 females captured during monthly collections. After a histological study of the gonads, the animals were classified during each season according to maturity stage. The fish were captured using a rod and reel, with cattle heart and worms as bait. Capture was selective, and only animals measuring more than $19 \mathrm{~cm}$ were collected.

The captured fish were anesthetized with benzocaine $(1 \mathrm{~g} / 10 \mathrm{~mL}$ alchool $+15 \mathrm{~L}$ water) and killed by hypoxia. The fish were then marked on the dorsal fin and transported in ice-filled coolers to a teaching Morfology Laboratory. Biometric data such as total weight $(\mathrm{Wt})$, total length $(\mathrm{Lt})$ and standard length (Lp) were measured.

After a ventral incision, sex and gonadal development were determined macroscopically as proposed by Bazzoli (2003). The gonads were removed, weighed on an analytical scale $(0.001 \mathrm{~g}$ precision), cut into fragments (around $2.0 \mathrm{~cm}$ ), identified and fixed in Bouin solution for $24 \mathrm{~h}$.
The liver was also removed and weighed on an analytical scale. Gonad and liver weight were used to calculate the hepatossomatic index [HSI $=(\mathrm{LW} / \mathrm{TW}) \mathrm{x} 100]$, where $\mathrm{LW}$ is the liver weight (Andrade et al., 2006), and the gonadosomatic index $[\mathrm{GSI}=(\mathrm{GW} / \mathrm{TW}) \mathrm{x} 100]$, where $\mathrm{GW}$ is the gonad weight (Vazzoler, 1996; Hojo et al., 2004). Following Braga's (2001) criteria, we assessed the abdominal fat index (AFI) visually, based on the proportion of fat deposition in the abdominal cavity, as follows: AFI I: 0 to $25 \%$ fat; AFI II: 26 to $50 \%$ fat, AFI III: 51 to $75 \%$ and AFI IV: 76 to $100 \%$.

The total weight/standard length ratio of the fish was based on the method proposed by Le Crên (1951), as mentioned by Costa et al. (2005). This ratio was applied to the pooled data of males and females using the equation $W=\alpha L^{b}$, where $\mathrm{W}=$ body weight, $\mathrm{L}=$ standard length, $\mathrm{a}=$ intercept (lna) obtained from weight and length data in each animal, and $b=$ regression coefficient.

The condition factor $(\mathrm{K})$ of each individual was estimated using the mathematical expression: $\mathrm{K}_{1}$ $=\mathrm{W} / \mathrm{L}^{\mathrm{b}}, \mathrm{K}_{2}=(\mathrm{W}-\mathrm{GW}) / \mathrm{L}^{\mathrm{b}}$, where $\mathrm{K}_{1}=$ total condition factor, $\mathrm{K}_{2}=$ somatic condition factor, $\mathrm{GW}=$ gonad weight and $\mathrm{b}=$ angular coefficient of total weight and standard length regression (this constant is related to the type of annual growth of the species), established by the equation: $W=\alpha L^{b}$ (Lima Júnior and Goitein, 2006).

The gonad fragments were subjected to the standard histological procedure of paraffin embedding and hematoxylin and eosin staining. The histological evaluation was performed by phase contrast microscopy at a $400 \mathrm{x}$ magnification, and oocyte diameter was measured with a micrometrical ocular. The characterization of oocyte and germ cell development and determination of the maturity stages were performed as proposed by Bazzoli (2003).

The reproductive period, gonadosomatic index, hepatosomatic index, abdominal fat, weight/length ratio and sex ratio were evaluated. The reproductive period was determined by the monthly distribution of mean GSI values and the maturity stage. 
Statistical analyses were performed using SAS (SAS, 1999) software. After data normality was verified, differences between oocyte diameter in each maturity stage were determined using variance analysis followed by the Tukey test for multiple comparisons $(\mathrm{P}<0.05)$.

A binomial distribution with a logit link function was used to analyze AFI. Data on GSI and HSI were analyzed by non-parametric procedures because non-normal distribution was observed even after transformations. The means were analyzed by the Kruskal-Wallis test followed by the chi-square test for comparisons of significant differences $(\mathrm{P}<0.05)$. The associations between GSI, HSI and AFI were analyzed using Spearman's Correlation. ANOVA for unbalanced randomized block design (blocked by season) was adopted to analyze the condition factor, which was followed by the SNK test for comparison among the significant differences $(\mathrm{P}<0.01)$.

\section{RESULTS AND DISCUSSION}

Four maturity stages of gonadal development were identified in the males: rest (Stage 1), initial maturity (Stage 2), advanced maturity (Stage 3) and spawned (Stage 4). In the females, we identified rest (Stage 1), initial maturity (Stage 2) and advanced maturity (Stage 3) of gonads. Immature animals were found because, according to a study by Vazzoler (1996), sexual maturity in piaparas occurs when they reach $19 \mathrm{~cm}$ in length. The animals that we captured were over $19.5 \mathrm{~cm}$ long. The ratio between total weight and standard length assesses the expected weight variation as a function of length and vice versa, in addition to indicating fish condition based on fat accumulation, overall well being and gonadal development. In the present study, the $b$ coefficient was 2.7856 , which, according to Vazzoler (1996), is characteristic of species with negative allometric growth (below 3.0). Regarding sex ratio, females predominated in 3 of the 4 seasons (Spring, summer and autumn).

Oocyte diameters in the different stages were: oocyte $\mathrm{I}=83.0$ to $214.6 \mu \mathrm{m}$; oocyte $\mathrm{II}=158.9$ to $337.0 \mu \mathrm{m}$; oocyte III $=221.5$ to $590.6 \mu \mathrm{m}$ and oocyte IV $=515.2$ to $963.0 \mu \mathrm{m}$. Oocytes I and II occurred in fish at any maturity stage, oocytes III occurred only in Stage 2 and 3 fish, and oocytes IV in Stage 3 fish. In general, oocytes of a same stage were similar in size, regardless of fish maturity stage, but oocytes II were larger in Stage 3 than in Stage 1 fish and oocytes II were larger in Stage 3 than in Stage 2 fish.

The relative frequency of the maturity stages across the seasons shows that males at rest and at initial maturity occurred throughout the study period (Figure 1). The onset of reproductive recruitment was observed in the spring, and Stage 3 fish occurred until autumn. However, in this season they represented only $20 \%$ of the captured specimens. Individuals in Stage 1 and 2 were observed in the winter, an indication that this is a gonad recovery period.

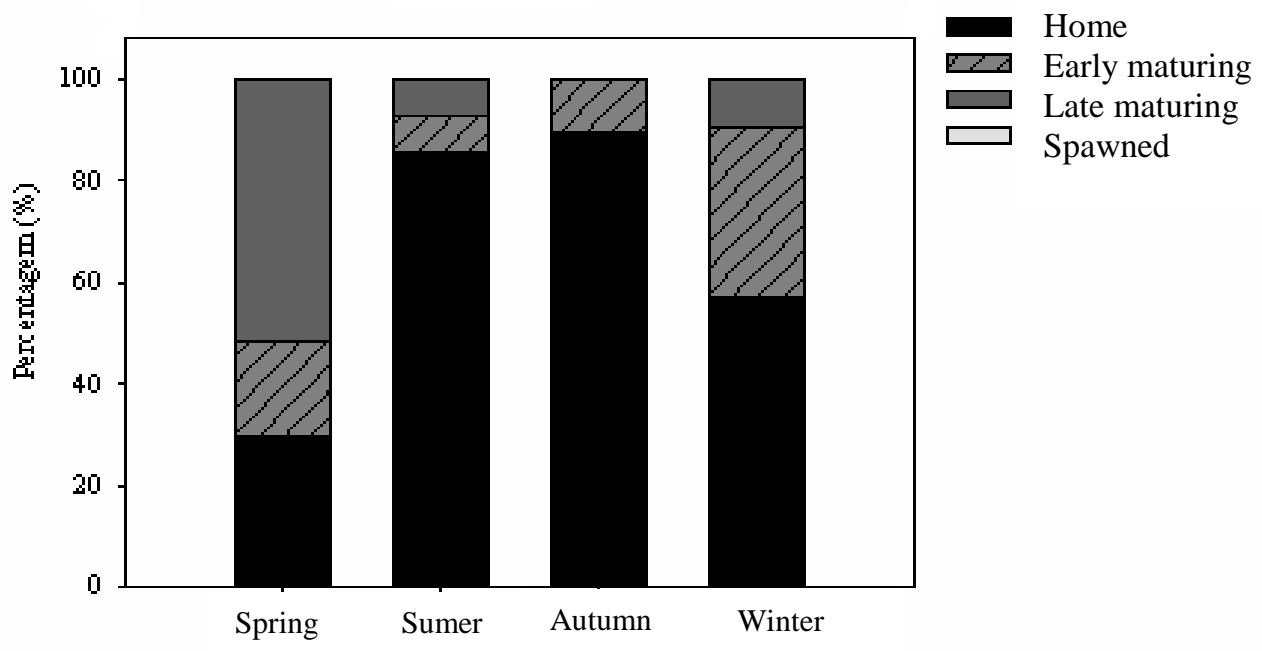

Figure 1. Relative frequency of male piaparas (Lepoıııs vvıusulens) at different maturity stages collected in each season (spring $n=13$, summer $n=8$, autumn $n=13$, winter $n=8$ ) downstream from the Funil Hydroelectric Power Station from Sept 2006 to Aug 2007. 
Males that were ready to reproduce appeared at the first rainfall peak (spring). The rainy season extended to autumn, when both precipitation and local temperature decreased (Figure 2).

Females in Stages 1 and 2 occurred throughout the entire study period. The beginning of the reproductive period was marked by the appearance of Stage 3 females. These mature females were observed until summer (Figure 3). Like the males, the appearance of females that were ready to reproduce coincided with the first rainfall peak in the beginning of spring, which contrasts with the autumn period when precipitation decreases. Air temperature also tended to increase from the end of the winter (Figure 2). No spawned females were observed.
GSI for males was higher in the spring than in the other seasons $(\mathrm{P}<0.05)$, suggesting that this is the reproductive season. GSI was lower in autumn than in the summer and spring $(\mathrm{P}<0.05)$, and in the winter it was similar to that recorded in autumn and summer (Table 1). It was observed that the reproductive period initiated right after the GSI peak. For females, GSI was higher in the spring $(\mathrm{P}<0.05)$ compared to the other seasons, making it the likely reproductive season. GSI was lower in the summer and autumn compared to winter and summer $(\mathrm{P}<0.05)$. In the winter, GSI increased again, and during this period we found Stage 3 females.

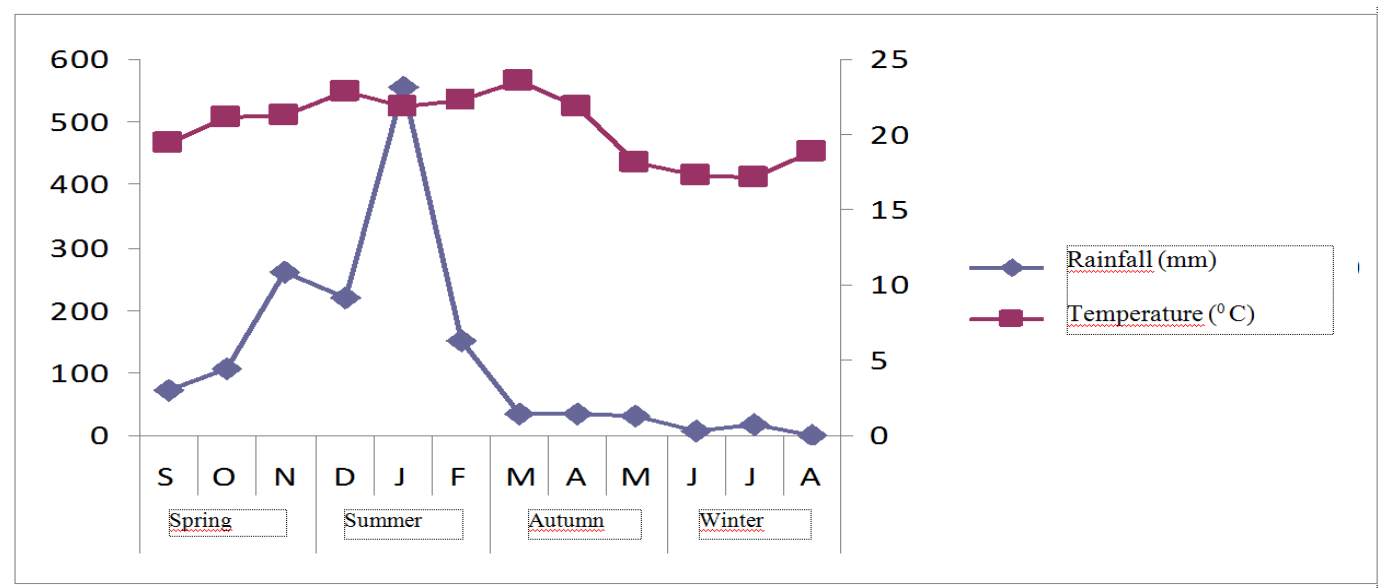

Figure 2. Mean seasonal air temperature $\left({ }^{\circ} \mathrm{C}\right)$ and rainfall $(\mathrm{mm})$ in the study area from Sept 2006 to Aug 2007. Source: UFLA Meteorological Station.

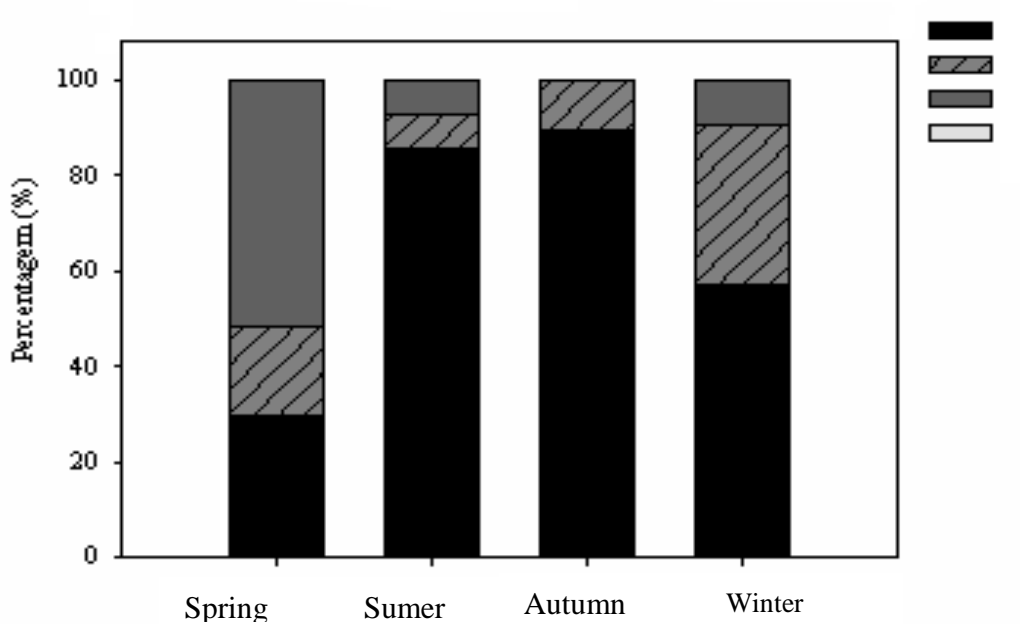

Home

Early maturing

Late maturing

Spawned

Figura 3. Relative frequency of female piaparas (Leporinus obtusidens) in different maturity stages collected in each season (spring $n=27$, summer $n=14$, autumn $n=16$, winter $n=8$ ) downstream from the Funil Hydroelectric Power Station from Sept 2006 to Aug 2007. 
Reproductive dynamics...

Table 1. Gonadosomatic index (GSI), hepathosomatic index (HSI), abdominal fat index (AFI) and condition factor $(\mathrm{K})$ for male and female piaparas (Leporinus obtusidens) collected from Sept 2006 to Aug 2007

\begin{tabular}{|c|c|c|c|c|c|c|c|c|c|c|}
\hline \multirow{2}{*}{ Season } & \multicolumn{5}{|c|}{ Male } & \multicolumn{5}{|c|}{ Female } \\
\hline & $\mathrm{GSI}^{1}$ & $\mathrm{HSI}^{1}$ & AFI & $\mathrm{K}^{2}$ & $\mathrm{~N}$ & $\mathrm{GSI}^{1}$ & $\mathrm{HSI}^{1}$ & AFI & $\mathrm{K}^{2}$ & $\mathrm{~N}$ \\
\hline Spring & $0.60 \mathrm{a}$ & $0.77 \mathrm{a}$ & 2 & $0.04 \mathrm{~b}$ & 13 & $2.18 \mathrm{a}$ & $0.77 \mathrm{a}$ & 1 & $0.05 a$ & 27 \\
\hline Summer & $0.22 b$ & $0.60 \mathrm{ab}$ & 2 & $0.03 \mathrm{c}$ & 8 & $0.45 \mathrm{c}$ & $0.82 \mathrm{a}$ & 2 & $0.04 \mathrm{~b}$ & 14 \\
\hline Autumn & $0.14 \mathrm{c}$ & $0.52 b$ & 1 & $0.04 \mathrm{ab}$ & 13 & $0.51 \mathrm{c}$ & $0.48 b$ & 1 & $0.05 \mathrm{a}$ & 16 \\
\hline Winter & $0.15 b c$ & $0.52 b$ & 2 & $0.05 \mathrm{a}$ & 8 & $0.63 b$ & $0.58 b$ & 2 & $0.05 \mathrm{a}$ & 8 \\
\hline
\end{tabular}

$\mathrm{N}=$ sample size

${ }^{1}$ Means followed by different letters in the same row are different (chi-square test, $\mathrm{P}<0.05$ ).

${ }^{2}$ Means followed by different letters in the same row are different (SNK test, $\mathrm{P}<0.01$ ).

The highest AFI values for males $(\mathrm{P}<0.05)$ occurred over the winter, spring and summer and decreased only in autumn. For females, they were higher in the winter and summer and decreased in the spring and autumn.

The condition factor for females was higher in the spring, autumn and winter compared to summer $(\mathrm{P}<0.05$; Table 1$)$. The total and somatic condition factors were calculated for females, and both showed the same tendency. This indicates that the condition factor was not affected by gonad weight in piaparas. The somatic condition factor was not used to determine the condition factor of male piaparas. The condition factor was higher in the winter than in the spring and summer, and in the summer it was lower than in the other seasons $(\mathrm{P}<0.05)$.

According to Chaves et al. (1998), the sex ratio of a population depends on several environmental and physiological factors such as the reproductive period, in which females tend to migrate to river headwaters before they mate with males. Although a 1:1 sex ratio is expected in fish populations, the proportion of females is usually higher in Characidae fish (Silva et al., 2004), which corroborates our findings.

We adopted oocyte diameter as maturity indicator. According to Crepaldi et al. (2006), this procedure is quick and widely used because, besides being highly precise, it can be used in vivo to evaluate fish maturity stage. Gonad recovery in female piaparas, in preparation for the next reproductive cycle, was observed from autumn to midwinter. This period is not associated to the onset of recruitment because a small number of animals were in Stages 2 and 3. However, the occurrence of females in these stages probably shows that abiotic and biotic factors stimulated oocyte development.

No females in the spawned maturity stage were observed, suggesting that the study area is not part of the migratory route of piaparas. Therefore, this area is most likely not used as reproductive sites by Leporinus obtusidens. The lack of spawned females and the abundance of Stage 1 females in summer are possibly a consequence of the dam construction. Females are in general more sensitive to environmental changes because they have complex gonad maturity and spawning processes such as vitellogenesis and a drastic increase in cells. External factors might therefore have inhibited female maturity and prevented spawning.

As reported in the results, the beginning of the rainy season marked the onset of the reproductive period for both males and females. In this period, both temperature and light period increased. The reproductive period of Characiformes in the Paraná Basin begins in the spring, but the highest frequency of reproducing species is found in the summer, when high temperatures are associated to high rainfall (Luiz et al., 2003). The reproductive period is also related to the rainy period for other species such as the cascudo (Loricariichthys platymetopon) (Querol et al., 2004) and sagüiru-do-raboamarelo (Steindachnerina insculpta) (Ribeiro et al., 2007).

The reproductive peak of the piau-vermelho (Leporinus copelandii) from the Muriaé and Paraíba do Sul rivers (Andrade et al., 2006) and 26 other fish species from the Volta Grande reservoir (Braga, 2001) also occurs during the period of highest temperatures and heaviest rainfall, when egg laying and spermiation is 
promoted. These results show the effect of precipitation on these species. However, according to Braga (2001), the climatic conditions are irregular over the years. The rainy season may arrive early or late from year to year, and these oscillations may affect biological reproduction processes.

Of the abiotic factors that affect fish reproduction, temperature and rainfall have been the focus of several studies (Silva et al., 2004). According to Leão et al. (1991), the banks of water reservoirs overflow during rainy periods, promoting the reproductive activity of fish, because the increased area for gamete release provides shelter that protects newly-hatched individuals against predators and favors the food supply. It was observed that the reproductive period of male piaparas followed the GSI peak in the spring. This finding was previously observed in Leporinus Copelandii (Andrade et al., 2006) and Loricariichthys platymetopon (Querol et al., 2004).

The occurrence of Stage 3 female piaparas decreased in the summer, the season with the highest temperature and rainfall in the study area. Other species reach maturity in the summer, when temperature and rainfall are high. The conditions in the study were, however, already suitable for piapara reproduction in November, when temperature and rainfall reached the highest levels (Fig. 3). Therefore, the reproductive peak of piaparas occurred in the spring rather than in the summer. Stage 3 male piaparas, at peak GSI, were first recorded in the spring. Nevertheless, some animals had already spermiated by this time, preventing GSI values from reaching high levels and causing them to decrease in the summer. Temperature and rainfall in autumn and winter tend to decrease, and in September, which marks the beginning of spring, they increase and remain high until summer. Summer is therefore the season with the highest occurrence of Stage 3 males and the highest GSI values.

GSI for both males and females increased according to gonad maturity stage. This was also observed for piracanjubas (Brycon orbignyanus) (Ganeco et al., 2001) and 26 other fish species from the Volta Grande reservoir (Braga, 2001). Female piaparas showed the highest GSI levels in the spring, when the first Stage 3 fish appeared. The lowest GSI levels were detected in the summer and autumn, when most of the females were likely in Stage 1. As in males, GSI seems to be directly associated to temperature and rainfall. In September (the end of winter and beginning of spring), when both temperature and rainfall increase, we found the highest occurrence of animals in Stage 3 and the highest GSI levels, whereas in autumn and winter, when these variables decrease, we observed many animals in Stage 1 with low GSI values.

Gonads of fish with annual reproductive cycles generally undergo marked changes as a result of the oocyte maturation process, which increases their volume and weight. The GSI profile recorded for piaparas over the four seasons showed these changes, providing strong evidence for identifying the reproductive period, i.e. when GSI reached its highest value. It can therefore be assumed that GSI is a good indicator for the reproductive period in piaparas.

HSI in male piaparas was lower in the summer, when most of the animals were in Stage 3 and had probably used glycogen and lipids as energy substrate in their 'piracema' (breeding runs). Similar findings were reported for Cichla monoculus (Chellappa et al., 2003) and L. copelandii (Andrade et al., 2006). In female piaparas, HSI was higher in the spring and summer. Stage 3 females occurred mostly in the spring, while in the summer these animals were mostly in Stage 1 (Table 1). Therefore, the liver is likely responsible for producing and releasing hepatic substances for yolk formation during oocyte and gonad maturation (Santos et al., 2004). HIS was also found in fish such as Leporinus copelandii (Costa et al., 2005) and the manjubas (Curimatella lepidura) (Alvarenga et al., 2006) at an advanced maturity stage because of high liver metabolic activity during the reproductive process.

The highest AFI levels found for males in some seasons may be related to food consumption during these periods, whereas the decrease in AFI by the end of the reproductive cycle is explained by lipid consumption during spermiation. In the reproductive period, teleost fish use stored fat for gonad maturation, converting energy reserves for reproductive purposes, as reported for the corvinas (Plagioscion squamosissimus) (Godinho et al., 
1997) and saguirus (Cyphocarax modestus) (Carmassi et al., 2008).

The lower fat accumulation in female piaparas during the spring may be due to the gonad maturation process detected in this season. These animals might obtain some resources by feeding, but the main energy sources are the fat deposits. Costa et al., (2005) states that fat content in fish is an important coefficient for the quantification of individual wellbeing, and the intrinsic seasonal variations of this parameter are associated to the feeding and reproductive patterns of each species.

The condition factor of female piaparas remained high throughout most of the year. It can thus be assumed that the individuals studied here had good body conditions, which deteriorated only in the summer. The best condition factor was observed in autumn and winter, when females were in Stage 1. From that point on, this variable did not exhibit the same seasonal distribution pattern, suggesting that it is not a good indicator of the reproductive period in piaparas. The condition factor in males decreased in the reproductive period, probably because food ingestion also decreases at this time. Reduced feeding may be associated to an increase in reproductive activities such as migration. This was not observed in females.

The diversion of certain energy reserves to enhance gonadal development and the effect of gonad weight on the condition factor is observed mainly in females; males are less affected by morphological gonad variations such as weight and volume (Vazzoler and Menezes, 1992).

The lowest condition factor of male piaparas was detected in the summer, when most of the animals were in Stage 3. As observed in females, this variable is not a good indicator of the reproductive period of male piaparas because its seasonal variation pattern does not match the GSI profile.

\section{CONCLUSIONS}

Females and males of reproductive age were observed during the late winter to summer and spring until autumn, respectively, peaking during the spring breeding for both sexes. The collection site of this study did not represent a species breeding site. Females captured downstream of the dam would be able to receive hormonal induction. Due to the absence of dumped animals and the incidence of follicular atresia, we can infer that the dam is acting directly on reproduction.

\section{REFERENCES}

AGOSTINHO, A.A.; GOMES, L.C.; PELICICE, F.M. Ecologia e manejo de recursos pesqueiros em reservatórios do Brasil. Maringá: Eduem, 2007. 501p.

AGOSTINHO, A.A.; THOMAZ, S.M.; GOMES, L.C. Conservation of the biodiversity of Brazil's inland waters. Cons. Biol., v.19, p.646-652, 2005.

ALVARENGA, E.R.; BAZZOLI, N.; SANTOS, G.B. et al. Reproductive biology \& feeding of Curimatella lepidura (Eigenmann \& Eigenmann) (Pisces, Curimatidae) in Juramento reservoir, Minas Gerais, Brazil. Rev. Bras. Zool., v.23, p.314-322, 2006.

ANDRADE, D.R.; PEREIRA, M.C.; JÚNIOR, M.V.V. et al. Acompanhamento de um ciclo reprodutivo anual em machos de piau-vermelho (Leporinus copelandii, Pisces, Anostomidae) em ambiente natural. Rev. Ceres, v.53, p.41-49, 2006.

BAZZOLI, N. Parâmetros reprodutivos de peixes de interesse comercial na região de Pirapora: águas, peixes e pescadores do São Francisco das Minas Gerais. Minas Gerais: PUC Minas/CNPq-PADCT, Belo Horizonte, 2003. 461p.

BRAGA, F.M.S. Reprodução de peixes (Osteichthyes) em afluentes do reservatório de Volta Grande, Rio Grande, Sudeste do Brasil. Iheringia - Série Zool., v.91, p.67-74, 2001.

CARMASSI, A.L.; SILVA, A.T.; RONDINELI, G.R. et al. Biologia populacional de Cyphocarax modestus (Osteichthyes, Curimatidae) no córrego Ribeirão Claro, município de rio Claro (SP). Biota Neotrop., v.8, p.100-113, 2008.

CHAVES, P.T.C.; OTTO, G. Aspectos biológicos de Diapterus rhombeus (cuvier) (teleostei, Gerreidae) na baia de Guaratuba, Paraná, Brasil. Rev. Bras. Zool., v.15, p.289-295, 1998. 
CHELLAPPA, S.; CÂMARA, M.R.; CHELLAPPA, N.T. et al. Reproductive ecology of a neotropical cichlid fish, Cichla monoculus (Osteichthyes: Cichlidae). Braz. J. Biol., v.63, p.17-26, 2003.

CREPALDI, D.V.; FARIA, P.M.C.; TEIXEIRA, E.A. et al. Biologia reprodutiva de surubim (Pseudoplatystoma coruYnscans). Rev. Bras. Reprod. Anim., v.30, p.159-167, 2006.

COSTA, A.P.R.; ANDRADE, D.R.; JUNIOR, M.V.V. et al. Indicadores quantitativos da biologia reprodutiva de fêmeas de piau-vermelho no Rio Paraíba do Sul. Pesqu. Agrop. Bras., v.40, p.789-795, 2005.

GANECO, L.N.; NAKAGH, L.S.O.; URBINATI, E.C. et al. Análise morfológica do desenvolvimento ovocitário de piracanjuba, Brycon orbignyanus, durante o ciclo reprodutivo. Bol. do Inst. de Pesca, v.27, p.131-138, 2001.

GODINHO, P.; SANTOS, G.; ASSIS, E.C. Some aspects of the reproduction of female corvine fish Plagioscion squamosissimus Heckel, 1840 (Scienidae) in a reservoir of southern Brazil. Trop. Freshwater Biol., v.6, p.17-26, 1997.

HOJO, R.E.S.; SANTOS, G.B.; BAZZOLI, N. Reproductive biology of Moenkhausia intermeida (Eigenmann) (Pisces, Characiformes) in Itumbiara Reservoir, Goiás, Brazil. Rev. Bras. Zool., v.21, p.519-524, 2004.

LEÃO, E.L.M.; LEITE, R.G.; CHAVES, P.T.C. et al. Aspectos da reprodução, alimentação e parasitofauna de uma espécie rara de piranha, Serrasalmus altuvei Ramirez, 1965 (Pisces, Serrasalmidae) do Baixo Rio Negro. Rev. Bras. Biologia, v.51, p.545-553, 1991.

LIMA JUNIOR, S.E.; GOITEIN, R. Fator de condição e ciclo gonadal de fêmeas de Pimelodus maculatus (Osteichthyes, Pimelodidae) no rio Piracicaba (SP, Brasil). Boletim do Inst. de Pesca, v.32, p.87-94, 2006.

LUIZ, E.A.; GOMES, L.C.; AGOSTINHO, A.A. et al. Influência de processos locais e regionais nas assembléias de peixes em reservatórios do Estado do Paraná, Brasil. Acta Scientiarum. Biol. Sci., v.25, p.107-114, 2003.
QUEROL, M.V.M.; QUEROL, E.; GOMES, N.N.A. Fator de condição gonadal, índice hepatossomático e recrutamento como indicadores do período de reprodução de Loricariichthys platymetopon (Osteichthyes, Loricariidae), bacia do rio Uruguai Médio, sul do Brasil. Iheringia. Série Zoologia, v.92, p.79-84, 2002.

QUEROL, M.V.M.; QUEROL, E.; PESSANO, E.F. Influência de fatores abióticos sobre a dinâmica da reprodução do cascudo viola Loricariichthys platymetopon (Isbrucker \& Nijssen, 1979) (Osteichthyes, Loricariidae), no reservatório da Estância Nova Esperança, Uruguaiana, bacia do rio, RS, Brasil. Biodiv. Pampeana, v.2, p.24-29, 2004.

RIBEIRO, V.M.A.; SANTOS, G.B.; BAZZOLI, N. Reproductive biology of steindachnerina insculpta (Fernandez-Yépez) (teleostei, Curimatidae) in Furnas reservoir, Minas Gerais, Brazil. Rev. Bras. Zool., v.24, p.71-76, 2007.

SANTOS, J.E.; BAZZOLI, N.; RIZZO, E. et al. Reproduction of the catfish Iheringichthys labrosus (Lütken) (Pisces, Siluriformes) in Furnas reservoir, Minas Gerais, Brazil. Rev. Bras. Zool., v.21, p.193-200, 2004.

SAS INSTITUTE. SAS SYSTEM: SAS/STAT. Version 8.0 (software). Cary. 1999.

SILVA, S.H.; MEURER, S.; ZANIBONI FILHO, E. Biologia alimentar e reprodutiva do peixe-cachorro (Oligosarcusjenynsii Günther, 1864) na região do alto rio Uruguai - Brasil. Acta Scientiarum. Biolog. Sci., v.26, p.175-179, 2004.

VAZZOLER, A.E.M. Biologia da reprodução de peixes teleósteos: teoria e prática. Maringá: EDUEM/Nupélia, 1996. 116p.

VAZZOLER, A.E.M.; MENEZES, N.A. Síntese de conhecimento sobre o comportamento reprodutivo dos Characiformes da América do Sul (Teleostei, Ostariophysi). Rev. Bras. Biologia, v.52, p.627-640, 1992. 